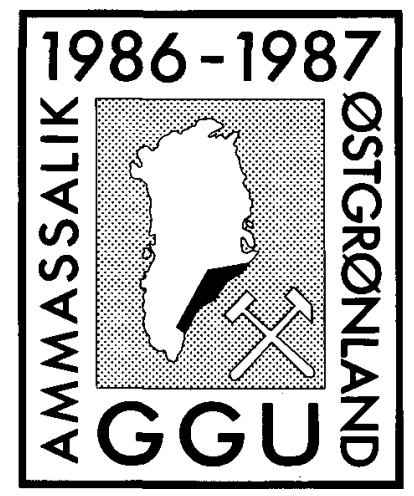

\title{
The Proterozoic mobile belt in the Ammassalik region, South-East Greenland (Ammassalik mobile belt): an introduction and re-appraisal
}

\author{
B. Chadwick, P. R. Dawes, J. C. Escher, C. R. L. Friend, \\ R. P. Hall, F. Kalsbeek, T. F. D. Nielsen, A. P. Nutman, \\ N. J. Soper and V. N. Vasudev
}

\begin{abstract}
The Ammassalik mobile belt is characterised by a regional layer cake structure of tectonically interleaved sheets of quartzo-feldspathic orthogneisses and supracrustal rocks. The sheets of supracrustal rocks are most abundant in the north of the belt and they include semi-pelitic kyanite-sillimanite gneisses, graphitic schists, marble, amphibolites and local peridotite. The sheets are regarded as parts of a disrupted supracrustal sequence, here termed the Síportôq supracrustal association. Preliminary isotopic age data suggest that most of the orthogneisses are late Archaean, although some have early Proterozoic ages. The Síportôq supracrustal association has yielded an early Proterozoic age. Amphibolite dyke swarms were emplaced at various stages in the evolution of the mobile belt. The Ammassalik belt has an ill-defined northern limit marked by heterogeneous retrogression of a granulite facies terrain up to $100 \mathrm{~km}$ wide. Most of the belt is at amphibolite facies, with its southern limit lying to the south of the area considered here.

The structure in the south is dominated by nappes and shear zones dipping NE within a wide tract of late Archaean orthogneisses intruded by amphibolite dyke swarms with relatively well preserved primary characteristics. The structure in the north is characterised by more pervasive deformation which gave rise to complex sequences of thrusting and nappe development propagating from the north. Large domes were superimposed on the nappe pile, perhaps as buoyancy phenomena. The dioritic Ammassalik Intrusive Complex (c. $1885 \mathrm{Ma}$ ) with its granulite facies assemblages is regarded as a late kinematic phenomenon. Major post-tectonic complexes of granite, diorite and gabbro (c. $1580 \mathrm{Ma}$ ) were intruded at a high level well after the close of the tectonism in the Ammassalik mobile belt.
\end{abstract}

\section{Introduction}

Much of the Ammassalik region surveyed in 1986 (fig. 1) is occupied by late Archaean orthogneisses and early Proterozoic supracrustal suites which have been variably deformed and metamorphosed at relatively deep crustal levels within an early Proterozoic mobile belt. This belt has been correlated with the Nagssugtoqidian of West Greenland by previous workers. Our surveys have led to important differences in the interpretation of the belt compared with previous work and they have raised questions concerning correlation with the Nagssugtoqidian. In this introduction we present a summary of our findings concerning the regional geology and chronology, details of which are contained in the articles that follow.

\section{Previous work}

The first geological investigations of the Ammassalik region were made in 1930-31 during a reconnaissance by Wager (1934), but detailed work did not begin until teams from the University of Birmingham, U. K., mapped the area between Kitak and the east of Angmagssalik Fjord (fig. 1) in 1967, 1969 and 1970 (Wright et al., 1973). Reconnaissance surveys of the coast of South-East Greenland between $63^{\circ}$ and $68^{\circ} \mathrm{N}$ in the late 1960s and continuing into the 1970s were organised by GGU and directed by D. Bridgwater and J. S. Myers (Bridgwater \& Gormsen, 1968, 1969; Andrews et al., 1973; Bridgwater \& Myers, 1979). The main framework of the geology of the Ammassalik region had therefore been established by the end of the $1970 \mathrm{~s}$, although most 


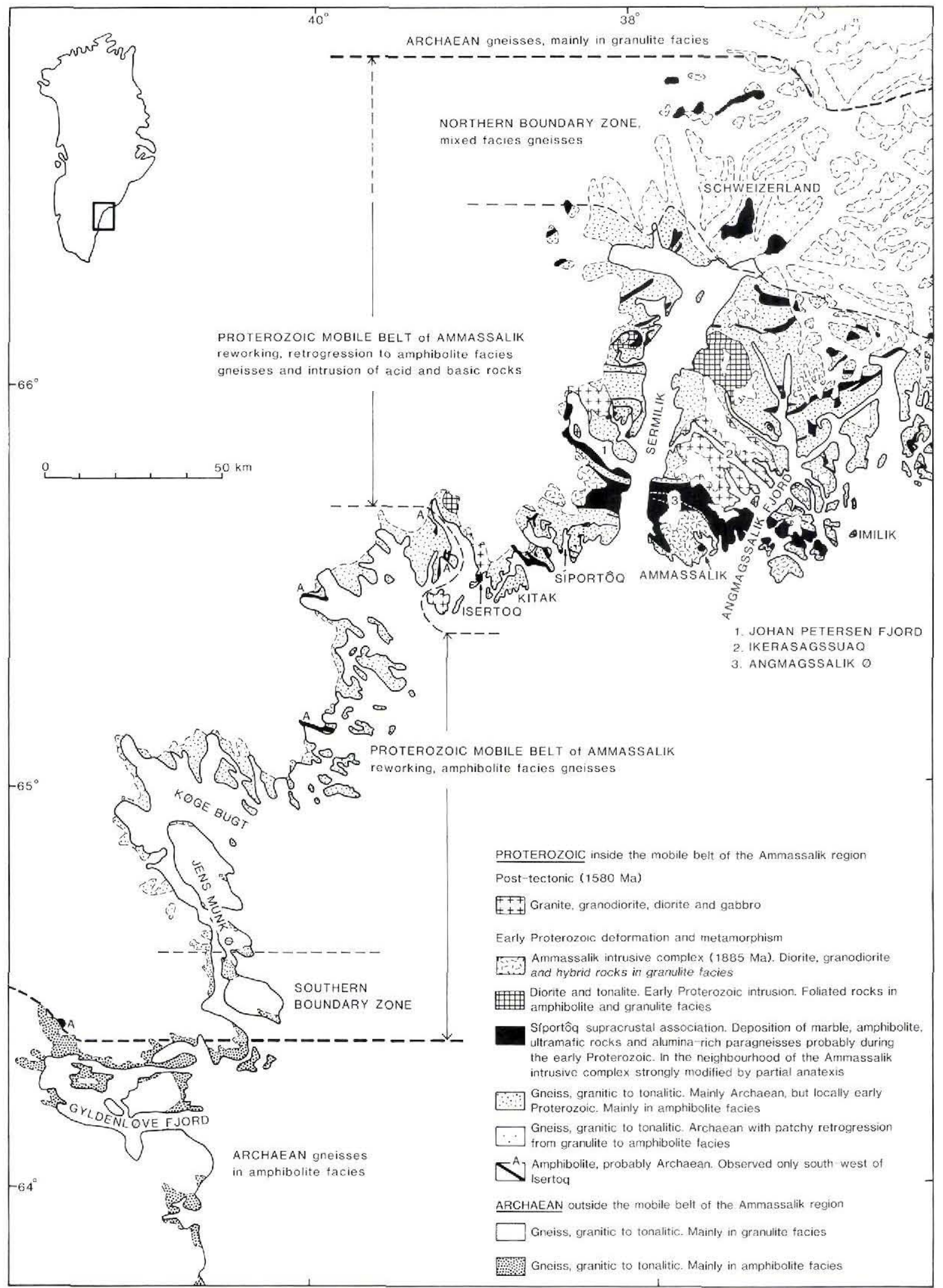

Fig. 1. Geological sketch of the Ammassalik mobile belt with localities mentioned in the text. 
of the remote mountainous interior remained largely unknown.

\section{Outline of the regional geology}

The Ammassalik region is most conveniently described in terms of two parts, the boundary between them being a zone of mylonites trending NW just north of Kitak (fig. 1). The southern part (Escher et al., this volume) is dominated by multiphase quartzo-feldspathic orthogneisses of presumed Archaean age. They contain abundant enclaves of amphibolite and local pods of metagabbro and ultrabasites, much of the metagabbro containing coarse, recrystallised crystals of plagioclase like those in the Archaean stratiform anorthosite complexes in southern West Greenland (Myers, 1985). Nunes et al. (1974) concluded that a U-Pb age of $2700 \mathrm{Ma}$ yielded by zircons from inclusions of gabbroanorthosite in orthogneisses on Kitak represents either a 'massive metamorphic episode' or the crystallisation of the anorthosite. The gneisses are host to swarms of discordant amphibolite dykes with relict doleritic textures. The gneisses and dykes are variably deformed and recrystallised to amphibolite facies assemblages in shear zones up to a few hundred metres in width. Many of the zones dip NE and include mylonites with locally intense linear fabrics plunging gently NW or SE. The geometry of deformed dykes and foliation in the gneisses shows that displacements in the shear zones were upwards from NE to SW, although linear fabrics suggest significant strike-slip displacements.

The northern part of the region in contrast includes numerous, broadly concordant, persistent sheets and lenses of rusty-brown supracrustal rocks in addition to orthogneisses similar to those in the south. This interleaving of gneisses and brown supracrustal rocks gives rise to a coarse layer cake structure. The layers of supracrustal rocks range in thickness from a few metres to about $1 \mathrm{~km}$. Estimates of thickness of intervening sheets of orthogneisses are difficult because of the effects of deformation, but the range is in the order of 10 metres to more than 1 kilometre.

Gneisses in the extreme north are at granulite facies (fig. 1). They are followed to the south by a zone of patchy retrogression, whilst the remainder of the northern part is dominated by amphibolite facies assemblages including sillimanite and kyanite in paragneisses. Small areas of granulite facies assemblages occur in orthogneisses within the amphibolite facies terrain, a relation also noted by Bridgwater et al. (1977). Granulite facies assemblages are characteristic of the Ammassalik Intrusive Complex in the south of the northern area (Friend \& Nutman, this volume). Suites of variably deformed amphibolite dykes are common in many of the orthogneisses, but they appear to be rare in the supracrustal rocks. Post-tectonic intrusions of gabbro, diorite and granite with an isotopic age of c. $1580 \mathrm{Ma}$ (Pedersen \& Bridgwater, 1979; Taylor et al., 1984) in the area of Angmagssalik $\varnothing$ and southwest of Kitak mark the youngest Precambrian event in the region.

\section{Quartzo-feldspathic orthogneisses and diorite- tonalite complexes}

The bulk of the orthogneisses are foliated, the term foliation here referring to the 1-30 cm-scale lithological layering formed by variations in biotite and hornblende content or by concordant seams and lenses of pegmatite. This foliation constitutes the earliest recognisable tectonometamorphic phenomenon in the orthogneisses, although it has been variably modified and enhanced by younger deformation and metamorphism. Most of the orthogneisses, including the Blokken gneiss of Bridgwater et al. (1978a), appear to be multiphase in the sense that they include relatively small-scale layering of different composition, some layers being rich in hornblende, others in biotite. Some of this layering may represent different phases of the magmatic precursors to the gneisses, some may represent variable degrees of assimilation of enclaves of amphibolitic and other compositions, whilst some may be a consequence of tectonometamorphic differentiation. No evidence was found to substantiate the reports by Myers $(1984,1987)$ that the gneisses at Blokken represent a younger suite cutting older gneisses with early fabrics (Dawes et al., this volume - Blokken). Some outcrops of multiphase orthogneisses in the northern area include slightly discordant sheets of younger grey orthogneisses. These younger orthogneisses may be more abundant further south, especially in the Síportôq region (fig. 1).

Large bodies of diorite-tonalite crop out within the orthogneisses in the north. One occurs within the patchily retrogressed granulite facies terrain but its limits are poorly defined, whilst two other bodies occur on opposite sides of Sermilik. The body east of Sermilik includes large areas of granulite facies assemblages. Metagabbroic amphibolite and granitic or granodioritic phases occur sporadically within each body, but they are dominated by variably deformed, coarse-grained biotitehornblende-feldspar quartz diorite or tonalite with accessory garnet in some instances: small mafic xenoliths are common locally. Deformation is commonly localised in narrow shear zones, but wider areas of foliated gneisses characterise many parts of the two principal bodies. Seams and pods of pegmatite are commonly associated with the foliated varieties of diorite-tonalite. 
The relation between the bodies of diorite-tonalite and surrounding multiphase orthogneisses is not understood because critical contacts were not seen. The diorite and related intrusive rocks are cut by the regional swarm of amphibolite dykes, although dykes are not abundant.

Preliminary isotopic age data suggest most of the multiphase orthogneisses are late Archaean (Pedersen \& Bridgwater, 1979; Bridgwater \& Myers, 1979; Kalsbeek \& Taylor, this volume), but some were intruded during the early Proterozoic (Kalsbeek \& Taylor, this volume), in agreement with the field evidence (Chadwick \& Vasudev, this volume).

\section{Síportôq supracrustal association}

This term is proposed here (see also Hall et al., this volume - Supracrustals) for the metasedimentary gneiss group of Wright et al. (1973) and associated ultrabasic and amphibolitic rocks found in the persistent sheets interleaved with the quartzo-feldspathic orthogneisses. The term is derived from Síportôq (fig. 1) where the supracrustal sheets are abundant and readily accessible. We assume that all of the rocks included in the Siportôq supracrustal association are of the same age, although suites of older supracrustal rocks may be present in some areas.

Paragneisses and schists variably migmatised by thin, broadly concordant seams and lenses of younger gneisses and pegmatites constitute the major part of the supracrustal association in the northern area. Mineral assemblages are dominated by biotite, muscovite, quartz and feldspar, with garnet, kyanite, sillimanite and graphite common as subordinate components. Some quartz-rich facies are rich in sulphides including pyrite, pyrrhotite and local chalcopyrite, and some garnetiferous paragneisses contain up to $11 \% \mathrm{MnO}$. Beds of grey marble, commonly with graphite and diopside, are prominent in some parts of the association.

Amphibolites are subordinate in volume to the metasedimentary component in the principal sheets of the Síportôq supracrustal association. They are concordantly intersheeted with paragneisses and range in thickness from $30 \mathrm{~cm}$ to $100 \mathrm{~m}$, thicker sheets generally being made up of a range of compositional types. The most common variety is compositionally banded and rich in garnet. Disseminated sulphides locally give rise to rusty weathering and a few amphibolites have veneers of malachite on joint surfaces. Pale varieties include garnet-hornblende-feldspar gneiss which is commonly associated with mafic amphibolite including hornblendites. Leucogabbroic gneisses occur in some instances. Whilst some amphibolites may represent tuffs, the bulk are interpreted as differentiates of basaltic intrusions. Some thinner sheets and pods have mineral assemblages identical to amphibolite dykes in the orthogneisses.

Ultramafic rocks are not important volumetrically in the Síportôq supracrustal association. They form pods or lenticular bodies up to $200 \mathrm{~m}$ wide by $1000 \mathrm{~m}$ long. Olivine and tremolite, commonly as coarse prisms and nodular intergrowths, are major constituents with subordinate green amphibole, anthophyllite, pale mica, chlorite and talc. Brown orthopyroxene occurs in some instances as coarse porphyroblasts. Dunitic varieties are rare. Pink corundum, rhodolite garnet, translucent bluish kyanite and honey-brown tremolite with potential as semi-precious gemstones occur in a metagabbro associated with one of the large ultramafic bodies in the Síportôq area (fig. 1).

The depositional environment of the Síportôq supracrustal association was dominated by additions of terrigenous material including quartz, feldspar and clay minerals. No sedimentary structures were found apart from coarse trough cross-bedding in some paragneisses in the Síportôq area (Hall et al. , this volume - Supracrustals). The high alumina content suggested by the locally abundant kyanite and sillimanite points to advanced weathering in the source area. Thick sheets of marble and the abundance of semi-pelitic gneisses suggest gentle subsidence of basins or shelf environments. None of the amphibolite sheets in the supracrustal gneisses contain unambiguous primary structures indicative of an eruptive volcanic parentage. Most appear to have been sills of basaltic composition that differentiated to layered complexes including gabbroic and peridotitic suites. Depositional environments and the tectonic setting of the supracrustal association are discussed further by Hall et al. (this volume - Supracrustals) and their probable early Proterozoic age is discussed by Kalsbeek \& Taylor (this volume).

\section{Relative age of the quartzo-feldspathic orthogneisses and the Siportôq supracrustal association}

This age relation is of fundamental importance in the interpretation of the regional geology, but because of the lack of reliable field criteria there is no agreement in the previous literature about the relative ages of the supracrustal rocks and the orthogneisses. Wager (1934) and Bridgwater et al. (1977) regarded the supracrustal suite as older than the orthogneisses, whereas Bridgwater \& Gormsen (1968) and Wright et al. (1973) thought that the supracrustal rocks and the orthogneisses represented an original cover-basement association.

Thin sheets of paragneiss and amphibolite and strings 
of ultramafic pods are common in some of the orthogneisses adjacent to thick sheets of supracrustal rocks, but sheets of orthogneiss are uncommon within thick sequences of supracrustal rocks. Sequences of intersheeted orthogneisses and thin sheets of paragneiss that persist for some kilometres are common in the northern part of the region. The orthogneisses are locally rich in enclaves of amphibolite and paragneiss which on the grounds of composition (some are graphitic) are regarded as part of the Síportôq association. These relations may be interpreted in terms of a magmatic, intrusive relation, with the orthogneisses being younger than the Síportôq supracrustal association.

On the other hand, limited isotopic data (see Kalsbeek \& Taylor, this volume) indicate that most of the orthogneisses are late Archaean whilst the supracrustal rocks are probably early Proterozoic, an age relation supporting the view of an original cover-basement relation. The fact that the Síportôq supracrustal association compares more closely with early Proterozoic suites in West Greenland than Archaean suites such as the IsuaAkilia and Malene associations (Bridgwater et al., 1976a; McGregor \& Mason, 1977; Chadwick \& Coe, 1983; Nutman, 1986; Hall et al., 1987a) elsewhere on the west coast lends further support to this view. Consequently, the layer cake structure is believed to have formed by tectonic interleaving in the form of thrust sheets or isoclinal fold cores, with concomitant or later deformation giving rise to attenuation and podding of some sheets of supracrustal rocks. This relation is similar to that described from the Rinkian of West Greenland by Pulvertaft (1986), although there is only limited field evidence for a cover-basement relation in the Ammassalik region (Chadwick \& Vasudev, this volume; Dawes, this volume). Whilst many of the enclaves in the orthogneisses may be regarded as tectonic pods, some of the orthogneisses are apparently Proterozoic and younger than the supracrustal association, a relation compatible with recent findings in the Nagssugtoqidian belt of West Greenland (Kalsbeek et al., 1987).

\section{Early Proterozoic dykes}

Swarms of discordant, relatively undeformed amphibolite dykes, locally with garnetiferous microgabbroic cores, occur throughout much of the orthogneisses in the southern area, with weakly uralitised dolerite dykes forming part of the swarms in the extreme south. Modification of the dykes to intensely deformed amphibolites has taken place in NE-dipping shear zones. Amphibolite dykes are common in the orthogneisses in the northern area but they are generally intensely deformed, appearing principally as disrupted sheets and pods. Igneous assemblages are not preserved in the northern area, although porphyritic and ophitic textures survive locally as pseudomorphs of fine-grained intergrowths including garnet, hornblende and plagioclase. Some dykes, particularly in areas of low strain, preserve yellow-green 'eclogitic' cores comprising an early clinopyroxene + garnet assemblage overgrown by hornblende and plagioclase (Nutman \& Friend, this volume).

In the extreme north primary intrusive phenomena including high-angle discordances and apophyses survive, but progressive deformation has given rise to severe disruption and podding of most of the amphibolite dykes south of the northern granulite facies terrain (fig. 1). Dykes are common in shear zones cutting across patchily retrogressed, granulite facies orthogneisses in the north (Bridgwater et al., 1977). The shear zones containing the dykes are the sites of retrogression as reported by previous workers, but we were unable to confirm that they are associated with regional dextral transcurrent movements described by Myers (1984; see Dawes et al., this volume - Northern boundary). Bridgwater et al. (1977), Bridgwater \& Myers (1979) and Myers (1984, 1987) suggested the dykes were intruded syntectonically into these shear zones, but field relations are also consistent with the interpretation that the dykes were intruded into pre-existing shear zones with later reactivation leading to deformation of the dykes, a relation recognised in West Greenland (Kalsbeek \& Zeck, 1986). The Charcot Fjelde dykes (Myers, 1984, 1987) appear to be part of the principal swarm of amphibolite dykes, their high angle discordances being preserved as a consequence of their occurrence in zones of low strain. Amphibolite dykes with unambiguous discordances are rare in the Síportôq supracrustal association compared with the orthogneisses. The paucity of dykes in the supracrustal association may however be more apparent than real because of the effects of deformation, a characteristic also noted by Wright et al. (1973).

The Síportôq area (fig. 1) includes sporadic swarms of thin mafic dykes which cut deformed amphibolite dykes in the orthogneisses. These dykes were first reported by Palmer (1971) who showed that they are characterised by variable proportions of diopside, hornblende, antiperthite, microcline and quartz with abundant accessory apatite and sphene. Our survey revealed several occurrences in the orthogneisses and supracrustal amphibolites in the Síportôq area of coarse breccias with hornblende-rich matrix compositions which may be similar to these dykes. However, the breccias are deformed and locally cut by amphibolite dykes, relations which suggest the breccias are older than the thin mafic dykes (Chadwick \& Vasudev, this volume). 
Time relations between dyke injection and tectonism in the southern area are relatively simple, with generation of nappes and deformation in the NE-dipping shear zones taking place after emplacement of the regional swarm. In contrast, relations in the northern part of the region are not clear because deformation is more intense and more pervasive. Many of the amphibolite dykes in the least deformed parts, which are represented principally by the granulite facies terrain and its patchily retrogressed borders in the extreme north, appear to have been emplaced into pre-existing shear zones that were subsequently reactivated to accommodate displacements upwards from north to south. The greater abundance of dykes in the orthogneisses compared with the supracrustal sheets in the northern part of the region may be interpreted in terms of dyke emplacement taking place preferentially in the orthogneisses before the tectonic interleaving that gave rise to the regional layer cake structure. Alternatively, preferential emplacement of dykes into the orthogneisses as a function of contrasting rheological properties may have occurred after the tectonic interleaving, a time relation favoured by Wright et al. (1973). Field relations suggest that emplacement of basic dykes took place at various stages in the evolution of the mobile belt, beginning with early dykes forming feeders to basaltic sills in the Síportôq supracrustal association as is probably the case at Grusgraven (Dawes, this volume) and continuing with emplacement at intervals during or between the tectonic phases. This interpretation is broadly in accord with Bridgwater \& Myers (1979) who argued that emplacement of dykes took place intermittently between $c$. 2600 and $2000 \mathrm{Ma}$. The correlation of the amphibolite dykes with suites of early Proterozoic dykes in Scotland and West Greenland by Wright et al. (1973) and Bridgwater \& Myers (1979) is also in accord with our findings.

\section{Structure}

The structure in the southern part of the region appears to be relatively simple compared with the north, being dominated by nappes and shear zones dipping NE with principal displacements from NE to SW: strike-slip displacement within the shear zones is indicated by intense sub-horizontal linear fabrics in mylonites. North of the belt of mylonites forming the boundary between the two principal parts of the Ammassalik region, the structure is dominated by complex modifications of the layer cake arrangement of the sheets of orthogneisses and supracrustal rocks. These modifications involve a complex sequence of thrusting from the north, folding and nappe formation, the details of which are not com- pletely understood. Large domes with intervening narrow synformal cusps were superimposed on early nappes, perhaps as buoyancy phenomena beneath a thick carapace of nappes and thrust sheets (Chadwick \& Vasudev, this volume).

Following the correlation of the Ammassalik region with the Nagssugtoqidian of West Greenland by Bridgwater \& Gormsen (1968, 1969), Bridgwater \& Myers (1979) interpreted the geological evolution of the Ammassalik region in terms of that of the Nagssugtoqidian mobile belt of West Greenland and differentiated between early 'Nag. 1' and later 'Nag. 2' structures. Nag. 1 is characterised by lateral shearing in steep shear zones of late Archaean or early Proterozoic age, whilst Nag. 2 embraces younger Proterozoic structures. We have been unable to distinguish unambiguous Nag. 1 and Nag. 2 structures in the Ammassalik region and, accordingly, the Nag. 1 and Nag. 2 terminology is not used in this report (cf. Kalsbeek, 1979).

\section{Ammassalik Intrusive Complex (AIC)}

This late kinematic complex (fig. 1; Friend \& Nutman, this volume) is dominated by dioritic rocks with orthopyroxene and biotite and subordinate basic rocks with orthopyroxene and clinopyroxene and granitic rocks with orthopyroxene. The complex has yielded a $\mathrm{U}-\mathrm{Pb}$ zircon age of $c .1885 \mathrm{Ma}$ (Hansen \& Kalsbeek, this volume). The contact zone between the AIC and its host comprises garnet-rich gneisses largely derived from paragneisses and minor orthogneisses, the zone being regarded as a contact metamorphic aureole. Gneisses derived from orthogneisses contain orthopyroxene, and paragneisses are transformed to sillimanite-garnet-biotite diatexites with local orthopyroxene. Sheets of granitic augen gneiss with garnet, biotite and local orthopyroxene are interpreted as aggregates of melt derived from surrounding rocks which accumulated close to the AIC. The diatectic gneisses grade from the contact zone into metatexites and then into paragneisses free of partial melt. There is also a gradation from orthopyroxenebearing granitic rocks through garnet-bearing gneisses into the regional hornblende-biotite assemblages of the grey orthogneisses. Sharp intrusive contacts between the AIC and the host garnetiferous gneisses are common. Back-veining of granitic mobilisate from the host gneisses includes a range of heterogeneous quartzofeldspathic rocks with garnet \pm orthopyroxene \pm biotite \pm sillimanite. Geobarometric indicators suggest emplacement of the AIC and generation of its aureole took place at depths of c. $20 \mathrm{~km}$ (Nutman \& Friend, this volume). 


\title{
Table 1. Principal stages in the evolution of the Ammassalik mobile belt
}

\begin{abstract}
c. $1580 \mathrm{Ma}$ : Intrusion of late granite-diorite-gabbro plutons of uncertain genetic association with the mobile belt.

c. 1885 Ma: Emplacement of the Ammassalik Intrusive Complex and granulite facies metamorphism in the tract extending west from Kulusuk to the Inland Ice.

Development of the regional layer cake structure of sheets of orthogneisses and the Síportôq supracrustal association by tectonic interleaving of older orthogneisses and intrusion of younger orthogneisses followed by thrusting, folding and nappe formation.

Emplacement of basic dykes, now mainly amphibolites, taking place prior to and during the principal tectonism.
\end{abstract}

Early Proterozoic depositional and igneous phases of the Síportôq supracrustal association. ?Basement of late Archaean orthogneisses with inclusions of older metagabbroic rocks and related amphibolites.

c. 3000-2600 Ma: Late Archaean evolution of the multiphase quartzo-feldspathic orthogneisses, including emplacement of their precursors into stratiform gabbro complexes, deformation and high-grade metamorphism (including granulite facies).

\section{Post-tectonic granite, diorite and gabbro complex}

The principal area of the complex lies in the northeast of Angmagssalik $\varnothing$ and northeast of Ikerasagssuaq, although post-tectonic granitic rocks are common in many parts of the northern area including Johan Petersen Fjord and Imilik (fig. 1). A major body of granitic rocks which is believed to be part of this suite occurs near Isertoq, immediately west of Kitak. Emplacement of the main complex appears to have taken place largely by stoping as indicated by large rotated blocks of the host gneisses in parts of the periphery of the complex. The sequence of injection beginning with gabbro and ending with granite is revealed by xenolith relations in many outcrops. Net-veining of earlier dark dioritic rocks by granite is evident in many areas. Our findings are largely in agreement with those of previous workers.

\section{Re-appraisal of the Proterozoic mobile belt in the Ammassalik region}

There are several major differences between our findings concerning the regional geology and chronology (Table 1) and the interpretation of the mobile belt of the Ammassalik region and its correlation with the Nagssugtoqidian of West Greenland by Bridgwater \& Gormsen $(1968,1969)$, Bridgwater \& Myers (1979) and Myers $(1984,1987)$. The principal differences include:

(a) The northern boundary of the belt is not as sharply defined as indicated by Bridgwater \& Myers (1979) and Myers $(1984,1987)$. Shear zones and thrusts exist well to the north within the granulite facies terrain, a characteristic also noted by Bridgwater et al. (1978a) and Myers et al. (1980), and a northern limit to Proterozoic activity remains to be established unambiguously. It appears to be a zone of heterogeneous retrogression up to $100 \mathrm{~km}$ wide.

(b) Our observations of the shear zones attributed to Nag. 1 in the north do not confirm the significant dextral displacement reported by Bridgwater \& Myers (1979) and Myers (1984, 1987). Limited LS fabric data and kinematic indicators indicate dip-slip displacement upwards from the north.

(c) The shear zones attributed to Nag. 1 affect interleaved orthogneisses and supracrustal rocks, suites of the latter elsewhere having yielded isotopic data suggesting an early Proterozoic age. It follows that the shear zones cannot be late Archaean.

(d) Because the Síportôq supracrustal association appears to be early Proterozoic, its tectonic fabrics cannot be late Archaean as suggested by Myers (1987).

(e) There is no justification for distinguishing the Blokken gneisses (Bridgwater et al., 1978a) as a suite separate from the bulk of the orthogneisses. Isotopic evidence (Kalsbeek \& Taylor, this volume; B. T. Hansen, personal communication, 1987) supports the view that these rocks are Archaean gneisses. Nevertheless, distinct bodies of diorite-tonalite exist elsewhere in the Ammassalik region, and at least one of these has a Proterozoic age (Kalsbeek \& Taylor, this volume).

(f) There is no simple relationship between the occurrence of basic dykes, shear zones and areas of retrogression of the granulite facies terrain in the north. Dykes may be abundant in granulite facies gneisses which have been unaffected by Proterozoic structures or retrogression, whilst areas with abundant shear zones and widespread effects of retrogression may contain no 
dykes. Dykes are commonly oblique to zones of shearing and retrogression.

(g) Shear zones in the southern part of the region are dominated not by greenschist facies but by amphibolite facies assemblages.

(h) The layer cake arrangement of orthogneisses and supracrustal rocks and younger thrusts, nappes and domes in the northern area which correlate broadly with Nag. 2 of Bridgwater \& Myers (1979) and Myers (1984, 1987) compare more closely with structures in the Rinkian than those in the Nagssugtoqidian in West Greenland (Pulvertaft, 1986). The shear zones in the south which they described as Nag. 2 may bear closer comparison with Nagssugtoqidian phenomena on the west coast.

In the light of these differences and because the Proterozoic mobile belt in the Ammassalik region does not compare closely with the Nagssugtoqidian of West Greenland, we propose that the Nagssugtoqidian terminology applied to the mobile belt in South-East Greenland by previous workers be abandoned. This proposal is supported by the apparent mismatch of lineaments revealed by aeromagnetic data (Thorning, 1986). Consequently, we propose that the Proterozoic mobile belt in the Ammassalik region be labelled the 'Ammassalik mobile belt'. This does not imply that we reject the possibility of correlation with the Nagssugtoqidian mo- bile belt, but that at present we regard this correlation as uncertain. The role of the post-tectonic granite-diorite-gabbro complexes, c. $1580 \mathrm{Ma}$, is not clear, although their high level of emplacement suggests they were intruded well after the close of the Ammassalikian tectonism. Tarney \& Saunders (1979) showed that the principal complex centred on Ikerasagssuaq (fig. 1) displays many features typical of Andean batholiths and the geochemical characteristics of its basic to acid components imply derivation directly from a mantle source. On the other hand, Taylor et al. (1984) have provided isotopic evidence which suggests a major crustal contribution.

The formation of depositional basins that accommodated the Síportôq sediments and igneous suites probably marked the initial stages of the Ammassalik mobile belt. The basin development was followed or accompanied by the intrusion of swarms of basic dykes. The earliest tectonic manifestation of the Ammassalik mobile belt appears to be the interleaving of the sheets of multiphase orthogneisses and the Síportôq supracrustal association. Emplacement of the Ammassalik Intrusive Complex c. $1885 \mathrm{Ma}$ ago (Hansen \& Kalsbeek, this volume) probably marked the closing stages of orogenic activity in the mobile belt. Metamorphism, however, appears to have continued until at least $c .1775 \mathrm{Ma}$ ago (Kalsbeek \& Taylor, this volume). 